\title{
COMPARATIVE STUDY OF LABOUR PROGRESS AND DELIVERY OUTCOME AMONG INDUCED VERSUS SPONTANEOUS LABOUR IN NULLIPAROUS WOMEN USING MODIFIED WHO PARTOGRAPH
}

\author{
Ojaswini Patel1, Sharmila Pradhan², Bulu Naik ${ }^{3}$
}

${ }^{1}$ Associate Professor, Department of Obstetrics and Gynaecology, VSSIMSAR, Burla, Odisha.

${ }^{2}$ Assistant Professor, Department of Obstetrics and Gynaecology, VSSIMSAR, Burla, Odisha.

${ }^{3}$ Postgraduate Student, Department of Obstetrics and Gynaecology, VSSIMSAR, Burla, Odisha.

\section{ABSTRACT}

\section{BACKGROUND}

There is scarcity of literature comparing spontaneous versus induced labour among nulliparous women. The main objectives of the study were: 1) To compare the progress and outcome of induced versus spontaneous labour among nulliparous women using the modified WHO partograph. 2) To compare partographically the outcome of labour by various induction methods.

\section{MATERIALS AND METHODS}

Comparative study involving nulliparous women at term with an indication for induction of labour. Those whose labours were induced compared with those on spontaneous labour, all labouring women were monitored using modified WHO partograph. Outcome measures were including mean duration of labour, eventual mode of delivery and the foetomaternal outcome.

\section{RESULTS}

75 women were compared in each group. There was no difference in mean age, gestational age at delivery, height, weight and preinduction Bishop's score in studies and control group. Induction delivery interval was shortest in oxytocin group (696 \pm 239 min). Caesarean section rate was high in vaginal misoprostol (8\%) group and equal in both oral misoprostol (6.7\%) and oxytocin (6.7\%) groups. The Apgar scores at 1 and 5 minutes were not significant between the groups. Neonates requiring NICU admission was lowest in oxytocin group (7\%). Maternal complications rate was lowest in oxytocin group (9.3\%) compared to other groups.

\section{CONCLUSION}

We therefore conclude that induced labour can be a safe procedure among nulliparous women if labour is partographically monitored. Also, it was observed that oxytocin was a better inducing agent.

\section{KEYWORDS}

Partograph, Oxytocin, Misoprostol.

HOW TO CITE THIS ARTICLE: Patel O, Pradhan S, Naik B. Comparative study of labour progress and delivery outcome among induced versus spontaneous labour in nulliparous women using modified WHO partograph. J. Evolution Med. Dent. Sci. 2017;6(23):1844-1849, DOI: 10.14260/Jemds/2017/407

\section{BACKGROUND}

Labour is a natural physiological process characterised by progressive increase in frequency, intensity and duration of uterine contractions resulting in effacement and dilatation of the cervix with descent of the foetus through the birth canal. This physiological process may at times become pathological. Failure to recognise would result in prolonged labour with resultant increase in foetomaternal morbidity and mortality.

More than $22 \%$ of all gravid women undergo induction of labour in the US and the overall rate of induction of labour in US has more than doubled since 1990 to $2006 .^{1}$

Induction of labour is the artificial initiation of uterine contractions prior to their spontaneous onset.

The ability to induce labour safely and efficiently is one of the most important developments in Obstetrics during the $2^{\text {nd }}$ half of this century. ${ }^{2}$ Despite the advances in basic knowledge, we have not come far in providing the

Financial or Other, Competing Interest: None.

Submission 10-02-2017, Peer Review 07-03-2017,

Acceptance 13-03-2017, Published 20-03-2017.

Corresponding Author:

Dr. Bulu Naik,

Room No. 102, Resident Doctors Hostel,

VSSIMSAR, Burla-768017, Sambalpur, Odisha.

E-mail: bulubelmunda@gmail.com

DOI: $10.14260 /$ jemds $/ 2017 / 407$

\section{(c) $(1) \ominus$}

obstetrician with safe, reliable and cost effective methods to induce labour with subsequent vaginal delivery. Oxytocin and prostaglandins are released during labour as a normal physiologic process. Hence, we have attempted to study these agents in detail. ${ }^{3}$

The development of safe and effective regimen for oxytocin administration has provided long desired control of induction of labour. Regarding oxytocin, its familiarity, safety and reliability has scored it as the agent of choice to induce labour. The major deficiency of oxytocin is a high failure rate in women with lower cervical scores and this has led to the search of other agents and methods of labour induction. ${ }^{3}$

Prostaglandins have achieved considerable attention for induction in women with unfavourable cervices. These are considered to be directly involved in the initiation of labour. In term pregnancy with an unfavourable cervix and an inactive myometrium, it seems logical to use this to ripen the cervix or induce labour or both. ${ }^{3}$

According to most authorities, the best way to monitor labour is with the help of a partograph. Partograph is a composite graphical record of key data (Maternal and foetal) during labour entered against time on a single sheet of paper. An accurate record of the progress in labour can be obtained by it. Any delay or deviation from normal may be detected quickly and managed accordingly. 
There is scarcity of literature comparing spontaneous versus induced labour among nulliparous women. It is pertinent to compare the outcome of labour among these groups using WHO partograph.

\section{Aims and Objectives}

The main objectives of the study were to compare the progress and outcome of induced versus spontaneous labour among nulliparous women using the modified WHO partograph. To compare partographically, the outcome of labour by various induction methods in terms of Success rate, Failure rate, Maternal complications, Foetal complications, Induction - Delivery interval and Mode of delivery.

\section{MATERIALS AND METHODS}

This prospective, comparative study was carried out at Department of Obstetrics and Gynaecology, VSSIMSAR, Burla for the duration of 2 years from November 2014 to October 2016. The study included all nulliparous pregnant women at term requiring induction of labour with singleton foetuses in vertex presentation. The women were eligible to be recruited once they got admitted to this hospital. Those with unfavourable cervix had induction with oral misoprostol (25 $\mathrm{mg}$ ) or vaginal misoprostol (25 $\mathrm{mg}$ ) or oxytocin (5 mIU) as per hospital protocol given below.

For conveniently comparison purpose and as per case load in this hospital during 2 years' period of study, equal number of sample size i.e. 75 for each group (total 300) were decided to be taken for all four groups (Labour induced with oral prostaglandin, labour induced with vaginal prostaglandin, labour induced with IV oxytocin and labour with spontaneous onset).

75 nulliparous women requiring induction of labour who fulfilled the inclusion criteria were serially recruited for each group (Labour induced with oral misoprostol, labour induced with vaginal misoprostol, labour induced with oxytocin) and compared with 75 consecutive nulliparous women who had spontaneous labour using modified WHO partograph.

The data of progress of labour and foetomaternal outcome obtained from each group were compared by using statistical measure.

\section{Inclusion Criteria}

Nulliparous with singleton vertex presenting pregnancy, either in latent phase of spontaneous labour or having an indication for induction of labour as laid down in the ACOG practice bulletin 114, 2009 are $^{1}$ Abruptio placentae, Chorioamnionitis, Foetal demise, Gestational hypertension,
Preeclampsia, eclampsia, Premature rupture of membranes, Post-term pregnancy, Maternal medical conditions (eg, diabetes mellitus, renal disease, chronic pulmonary disease, chronic hypertension, antiphospholipid syndrome), Foetal compromise (eg, severe foetal growth restriction, isoimmunisation, oligohydramnios) and Logistic reasons like Risk rapid labour, History rapid labour, Distance from the hospital, Psychosocial indication.

\section{Exclusion Criteria}

All multiparous patients and nulliparous pregnant women having a contraindication for induction of labour as laid down in the ACOG practice bulletin $2009^{1}$ are placenta or vasa praevia, Abnormal foetal lie, cord presentation, prior classical uterine incision, prior myomectomy or uterine unification surgery entering the endometrial cavity, active genital herpes infection and invasive cervical carcinoma.

\section{Protocol of Induction with Oral Misoprostol}

Induction with oral misoprostol was started with the initial dose of 25 micrograms. Dosage was repeated every 4 hours until an adequate contraction pattern set in ( 3 contraction in 10 minutes).

Maximum allowable doses were six (150 micrograms of the drug). If labour did not ensue, even after 4 hours following last dose it was considered as failed induction and other methods of induction like oxytocin was tried.

\section{Protocol of Induction with Vaginal Misoprostol}

Patients assigned to the intravaginal misoprostol group had 25 micrograms tablet or one fourth of a 100 microgram inserted into the posterior fornix of the vagina. If the patient was not in adequate labour (Fewer than 3 contractions in 10 minutes) and the Bishop's score was $<6$, misoprostol administration was repeated every 4 hours. The maximal dose of misoprostol was 150 micrograms (6 doses).

If labour did not ensue even after 4 hours following last dose, it was considered as failed induction.

\section{Protocol of Induction with Oxytocin}

Oxytocin was delivered in a high dose manner according to the arithmetic escalation protocol given in the "Management of Labour" by Arulkumaran. ${ }^{4}$ The infusion rate was begun at 5 milliunits/minute and increased in 5 milliunits/minute increments every 30 minutes depending on the frequency and strength of contractions. Maximum dose allowed was 40 milliunits per minute.

\section{RESULTS}

\begin{tabular}{|c|c|c|c|c|c|c|}
\hline \multicolumn{2}{|c|}{ Characteristics } & $\begin{array}{c}\text { Oral } \\
\text { Misoprostol }\end{array}$ & $\begin{array}{c}\text { Vaginal } \\
\text { Misoprostol }\end{array}$ & Oxytocin & $\begin{array}{c}\text { Spontaneous } \\
\text { Labour }\end{array}$ & Significance \\
\hline \multicolumn{2}{|c|}{ Age (yrs.) } & 22.6 & 22.5 & 22.4 & 22.45 & $P=0.947$ \\
\hline \multicolumn{2}{|c|}{ Weight (kg) } & 57.3 & 56.3 & 56.6 & 58.5 & $P=0.156$ \\
\hline \multicolumn{2}{|c|}{ Height $(\mathrm{cm})$} & 155.7 & 156.4 & 156.4 & 156.5 & $\mathrm{P}=0.453$ \\
\hline \multicolumn{2}{|c|}{ Gestational Age (weeks) } & 39.4 & 39.2 & 39.1 & 39.2 & $P=0.636$ \\
\hline \multirow{3}{*}{$\begin{array}{c}\text { Pre-Induction } \\
\text { Bishop } \\
\text { Score N (\%) }\end{array}$} & $\leq 3$ & $16(21)$ & $21(28)$ & $20(27)$ & $20(27)$ & \\
\hline & $4-5$ & $57(76)$ & $48(64)$ & $46(61)$ & $31(41)$ & \\
\hline & $6-7$ & $2(3)$ & $6(8)$ & $9(12)$ & $24(32)$ & \\
\hline \multicolumn{7}{|c|}{ Table 1. Demographic Data } \\
\hline
\end{tabular}


The groups were comparable for their age, weight, height, gestational age and their pre-induction Bishop's score.

\begin{tabular}{|c|c|c|c|}
\hline Indications & $\begin{array}{c}\text { Oral } \\
\text { Misoprostol }\end{array}$ & $\begin{array}{c}\text { Vaginal } \\
\text { Misoprostol }\end{array}$ & Oxytocin \\
\hline PROM & 24 & 21 & 51 \\
\hline PD & 21 & 24 & 12 \\
\hline PE & 17 & 18 & 9 \\
\hline IUD & 13 & 12 & 3 \\
\hline Total & 75 & 75 & 75 \\
\hline \multicolumn{3}{|c|}{ Table 2. Indications for Induction } \\
\hline
\end{tabular}

$\mathrm{X}_{2}=30.986, \mathrm{p}=0.000$

In majority of the cases, it was PROM followed by PostDatism as the main indication.

\begin{tabular}{|c|c|c|c|}
\hline $\begin{array}{l}\text { I-D Interval } \\
\text { (min) }\end{array}$ & $\begin{array}{c}\text { Oral } \\
\text { Misoprostol } \\
(n=70) \\
N(\%)\end{array}$ & $\begin{array}{c}\text { Vaginal } \\
\text { Misoprostol } \\
(\mathrm{n}=69) \\
\mathrm{N}(\%)\end{array}$ & $\begin{array}{c}\text { Oxytocin } \\
\text { (n= 70) } \\
N(\%)\end{array}$ \\
\hline $\begin{array}{c}300-480 \\
5-8 \text { hrs. }\end{array}$ & $6(8.6)$ & $3(4)$ & $11(16)$ \\
\hline $\begin{array}{l}481-720 \\
8-12 \text { hrs. }\end{array}$ & $29(41)$ & $15(22)$ & $26(37)$ \\
\hline $\begin{array}{c}721-960 \\
12-16 \text { hrs. }\end{array}$ & $17(24)$ & $15(22)$ & $24(34)$ \\
\hline $\begin{array}{l}961-1440 \\
16-24 \text { hrs. }\end{array}$ & $18(25.7)$ & $24(35)$ & $9(13)$ \\
\hline $\begin{array}{l}1441-2250 \\
24-37.5 \text { hrs. }\end{array}$ & - & $12(17)$ & - \\
\hline Mean \pm SD & $804 \pm 276$ & $1080 \pm 503$ & $696 \pm 239$ \\
\hline \multicolumn{4}{|c|}{ Table 3. Induction to Delivery Interval } \\
\hline
\end{tabular}

Subjects in the oxytocin group more likely had vaginal delivery (53\%) within 12 hours of the start of induction. But subjects in the oral misoprostol group more likely had vaginal delivery (50\%) within 12 hours of the start of induction.

\begin{tabular}{|c|c|c|c|}
\hline $\begin{array}{c}\text { Change in } \\
\text { Bishop's } \\
\text { Score }\end{array}$ & $\begin{array}{c}\text { Oral } \\
\text { Misoprostol } \\
\text { N (\%) }\end{array}$ & $\begin{array}{c}\text { Vaginal } \\
\text { Misoprostol } \\
\text { N (\%) }\end{array}$ & $\begin{array}{c}\text { Oxytocin } \\
\text { N (\%) }\end{array}$ \\
\hline Less than 3 & $24(32)$ & $30(40)$ & $24(32)$ \\
\hline $3-6$ & $51(68)$ & $39(52)$ & $30(40)$ \\
\hline More than 6 & - & $6(8)$ & $21(28)$ \\
\hline Total & 75 & 75 & 75 \\
\hline \multicolumn{4}{|c|}{ Table 4. Change in Bishop's Score } \\
\hline
\end{tabular}

$\mathrm{X}_{2}=34.893, \mathrm{p}=0.000(<0.05)$

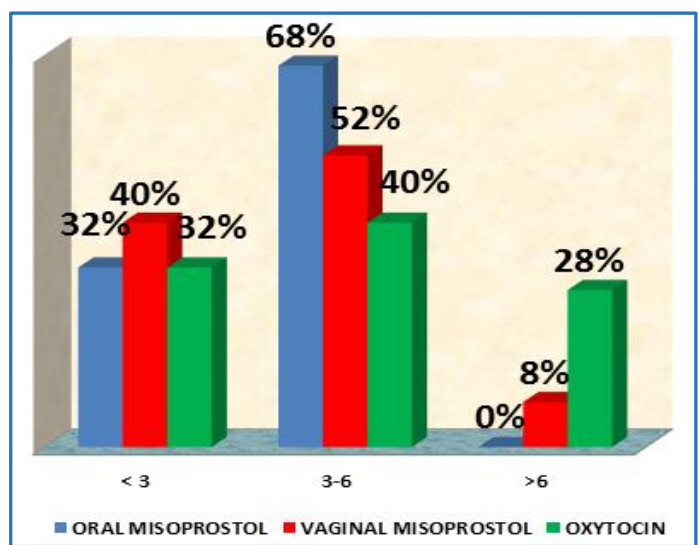

Graph 1. Change in Bishop's Score
The oxytocin group showed a better improvement in the Bishop's score after a 6-hour period when compared to vaginal misoprostol group.

\begin{tabular}{|c|c|c|c|c|}
\hline Groups & $\begin{array}{c}\text { Normal } \\
\text { Delivery } \\
(\%)\end{array}$ & $\begin{array}{c}\text { Instrumental } \\
(\mathrm{F}+\mathrm{V})(\%)\end{array}$ & $\begin{array}{l}\text { LSCS } \\
(\%)\end{array}$ & Total \\
\hline $\begin{array}{c}\text { Oral } \\
\text { Misoprostol }\end{array}$ & $65(86.7)$ & $5(6.7)$ & $5(6.7)$ & 75 \\
\hline $\begin{array}{c}\text { Vaginal } \\
\text { Misoprostol }\end{array}$ & $65(86.7)$ & $4(5.3)$ & $6(8 \%)$ & 75 \\
\hline Oxytocin & $65(86.7)$ & $5(6.7)$ & $5(6.7)$ & 75 \\
\hline $\begin{array}{c}\text { Spon- } \\
\text { taneous } \\
\text { Labour }\end{array}$ & $63(84)$ & $8(10.7)$ & $4(5.3)$ & 75 \\
\hline \multicolumn{5}{|c|}{ Table 5. Mode of Deliver } \\
\hline
\end{tabular}

$\mathrm{X}_{2}=2.083, \mathrm{P}=0.912$

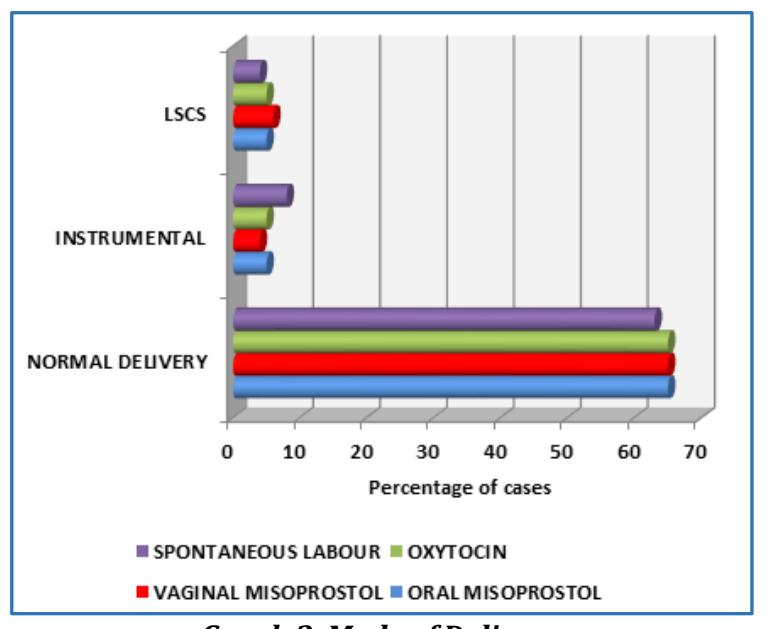

Graph 2. Mode of Delivery

Three $(4 \%)$ women in the oral misoprostol group had failed induction and two had foetal distress, so total five women underwent caesarean section.

Four (5.3\%) women in the vaginal misoprostol group had failed induction and two had foetal distress, so total six women underwent caesarean section.

Two (2.7\%) women in oxytocin group had failed induction and three had foetal distress, so total five women underwent caesarean section.

In present study failed induction were more in the vaginal misoprostol group (5.3\%) and less in the oxytocin group $(2.7 \%)$.

Four women of spontaneous labour underwent caesarean section because of foetal distress.

Caesarean rate was high in induced groups as compared to spontaneous group.

Instrumental delivery was more in case of spontaneous group when compared to induced delivery groups. 


\begin{tabular}{|c|c|c|c|c|}
\hline Perinatal Outcome & $\begin{array}{c}\text { Oral } \\
\text { Misoprostol N (\%) }\end{array}$ & $\begin{array}{c}\text { Vaginal } \\
\text { Misoprostol N (\%) }\end{array}$ & $\begin{array}{c}\text { Oxytocin } \\
\text { N (\%) }\end{array}$ & $\begin{array}{c}\text { Spontaneous } \\
\text { Labour N (\%) }\end{array}$ \\
\hline Birth Weight (gms) (Mean) & 2624 & 2742 & 2757 & 2720 \\
\hline Apgar at 1' (Mean) & 6.5 & 6.2 & 6.5 & 6.4 \\
\hline Apgar < 7 at 1' & $30(47.6)$ & $46(73)$ & $39(54)$ & $45(60)$ \\
\hline Apgar at 5' (Mean) & 8.4 & 8.2 & 8.4 & 8.7 \\
\hline Apgar < 7 at 5' & $4(6)$ & $3(4.7)$ & $6(8)$ & $6(8)$ \\
\hline Meconium & $4(6)$ & $6(9.5)$ & $7(9.7)$ & $3(4)$ \\
\hline Resuscitation & $6(9.5)$ & $6(9.5)$ & $5(7)$ & $5(6.6)$ \\
\hline NICU Admission & $7(11)$ & $6(9.5)$ & \\
\hline
\end{tabular}

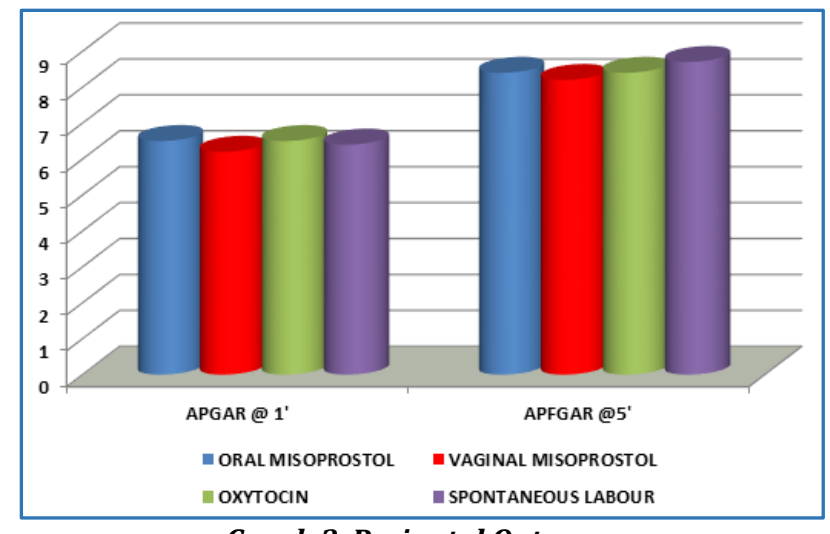

Graph 3. Perinatal Outcome

\begin{tabular}{|c|c|c|c|c|}
\hline $\begin{array}{c}\text { Compli } \\
\text { cations }\end{array}$ & $\begin{array}{c}\text { Oral } \\
\text { Miso- } \\
\text { Prostol } \\
\text { N (\%) }\end{array}$ & $\begin{array}{c}\text { Vaginal } \\
\text { Miso- } \\
\text { prostol } \\
\text { N (\%) }\end{array}$ & $\begin{array}{c}\text { Oxytocin } \\
\text { N (\%) }\end{array}$ & $\begin{array}{c}\text { Spont- } \\
\text { aneous } \\
\text { Labour } \\
\text { N (\%) }\end{array}$ \\
\hline Cervix Tear & $4(5.3)$ & $3(4)$ & $1(1.3)$ & $3(4)$ \\
\hline Tachysystole & - & $3(4)$ & $4(5.3)$ & - \\
\hline $\begin{array}{c}\text { Postpartum } \\
\text { Haemo- } \\
\text { rrhage }\end{array}$ & $4(5.3)$ & $3(4)$ & $2(2.7)$ & $2(2.7)$ \\
\hline $\begin{array}{c}\text { Vaginal Wall } \\
\text { Tear }\end{array}$ & - & - & - & $3(4)$ \\
\hline $\begin{array}{c}\text { Prolonged } \\
\text { 3rd Stage }\end{array}$ & - & $1(1.3)$ & - & \\
\hline Total & $\mathbf{8 ~ ( 1 0 . 7 )}$ & $\mathbf{1 0}(13)$ & $\mathbf{7 ~ ( 9 . 3 ) ~}$ & $\mathbf{8 ( 1 0 . 7 )}$ \\
\hline \multicolumn{5}{|c|}{ Table 7. Maternal Complications } \\
\hline
\end{tabular}

\section{DISCUSSION}

"The spontaneous onset of labour is a robust and effective mechanism... and should be given to operate on its own. We should only induce labour when we are sure that we can do better."

\section{Sir Alec Turnbull (1976)}

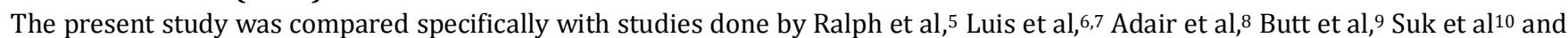
Abramovici et al ${ }^{11}$ and Ernest. 12

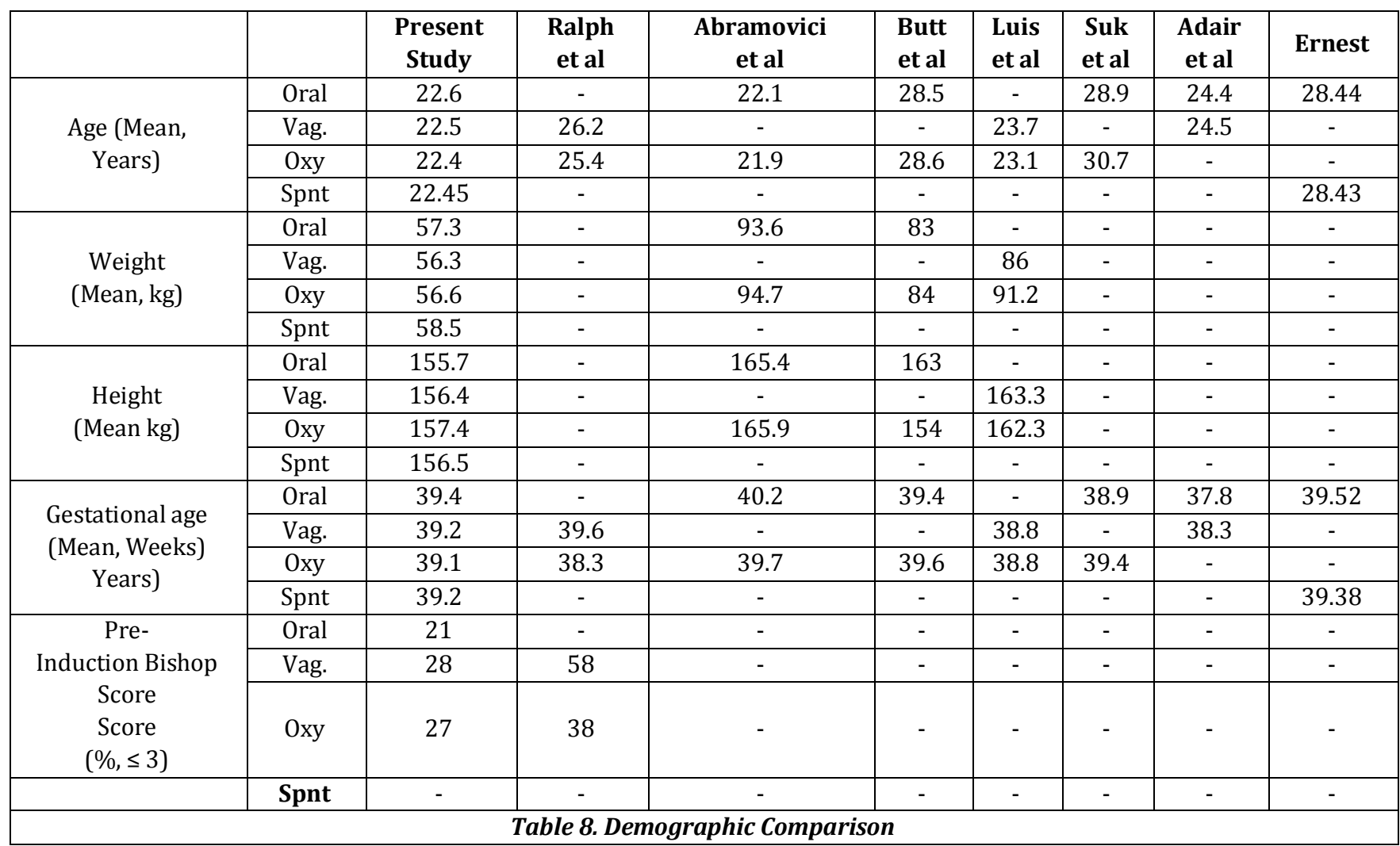


Our demographic pattern came close to that of Ralph et al, Butt et al and Luis et al.

In present study, the pre-induction Bishop scores were comparable to that of Ralph. We could not compare it with other studies, as they had different cut-off criteria.

Lower mean age of the participants can be attributed to higher number of primigravidae in present study group.

In the present study, majority of the cases indications was premature rupture of membranes or postdatism as per ACOG inclusion and exclusion criteria.

\begin{tabular}{|c|c|c|c|}
\hline \multirow{2}{*}{} & \multicolumn{3}{|c|}{ Mean Induction Delivery Interval (Min) } \\
\cline { 2 - 4 } & Oral & Vaginal & Oxytocin \\
\hline Present study & 804 & 1080 & 696 \\
\hline Butt et al & 720 & - & 501 \\
\hline Suk et al & 660 & - & 1116 \\
\hline Luis et al & - & 662 & 1105 \\
\hline Abramovici et al & 1104 & - & 864 \\
\hline Adair et al & 750 & 844 & - \\
\hline \multicolumn{4}{|c|}{ Table 9. Induction to Delivery Interval Comparison } \\
\hline
\end{tabular}

In the present study, the induction delivery interval is significantly shorter statistically in the oxytocin group when compared with the misoprostol groups, which is agreed with those of Butt et al and Abramovici et al where they studied oral misoprostol with oxytocin induction.

Subjects in the oxytocin group more likely had vaginal delivery (53\%) within 12 hours of the start of induction.

\begin{tabular}{|c|c|c|c|c|c|}
\hline & & $\begin{array}{l}\text { Oral } \\
\text { Miso }\end{array}$ & $\begin{array}{l}\text { Vaginal } \\
\text { Miso }\end{array}$ & Oxy. & $\begin{array}{c}\text { Spont } \\
\text { Labour } \\
\text { L }\end{array}$ \\
\hline \multirow{3}{*}{$\begin{array}{c}\text { Present } \\
\text { Study }\end{array}$} & Normal VD & 86.7 & 86.7 & 86.7 & 84 \\
\hline & Instrumental & 6.7 & 5.3 & 6.7 & 10.7 \\
\hline & C-section & 6.7 & 8 & 6.7 & 5.3 \\
\hline \multirow{3}{*}{ Ralph et al } & Normal VD & - & 63 & 58 & - \\
\hline & Instrumental & - & 13 & 14 & - \\
\hline & C-section & - & 23 & 29 & - \\
\hline \multirow{3}{*}{ Luis et al } & Normal VD & - & 58 & 54 & - \\
\hline & Instrumental & - & 20 & 25 & - \\
\hline & C-section & - & 22 & 21 & - \\
\hline \multirow{3}{*}{ Suk et al } & Normal VD & 70 & - & 68 & - \\
\hline & Instrumental & 25 & - & 25 & - \\
\hline & C-section & 5 & - & 8 & - \\
\hline $\begin{array}{c}\text { Abramovici } \\
\text { et al }\end{array}$ & C-section & 24 & - & 23 & - \\
\hline Adair et al & C-section & 18 & 15 & - & - \\
\hline \multirow{3}{*}{ Ernest } & Normal VD & 64.7 & - & - & 72.1 \\
\hline & Instrumental & - & - & - & 7.3 \\
\hline & C-section & 35.3 & - & - & 20.6 \\
\hline
\end{tabular}

In the present study, the routes of delivery did differ significantly between the four study groups. Vaginal misoprostol group had highest caesarean rate of $8 \%$ comparable with Luis et al, followed by equal in both oxytocin group and oral misoprostol group (6.7\%).

\begin{tabular}{|c|c|c|c|c|c|}
\hline & & $\begin{array}{c}\text { Apgar } \\
<7 \text { at } 1 \text { min } \\
\end{array}$ & $\begin{array}{c}\text { Apgar } \\
<7 \text { at } 5 \text { min } \\
\end{array}$ & Resuscitation & $\begin{array}{c}\text { NICU } \\
\text { Admission }\end{array}$ \\
\hline \multirow{4}{*}{$\begin{array}{l}\text { Present } \\
\text { Study }\end{array}$} & Oral $(n=63)$ & $30(47.6)$ & $4(6)$ & $6(9.5)$ & $7(11)$ \\
\hline & Vaginal $(n=63)$ & $46(73)$ & $3(4.7)$ & $6(9.5)$ & $6(9.5)$ \\
\hline & $\begin{array}{l}\text { Oxytocin } \\
(\mathrm{n}=72)\end{array}$ & $39(54)$ & $6(8)$ & $7(9.7)$ & $5(7)$ \\
\hline & Spont. labour $(\mathrm{n}=75)$ & $45(60)$ & $6(8)$ & $5(6.6)$ & $6(8)$ \\
\hline \multirow{2}{*}{ Butt et al } & Oral & 16.4 & 16.4 & - & 18.2 \\
\hline & Oxytocin & 16.4 & 16.4 & - & 16.15 \\
\hline \multirow{2}{*}{ Suk et al } & Oral & - & - & - & 7.5 \\
\hline & Oxytocin & - & - & - & 10 \\
\hline \multirow{2}{*}{ Luis et al } & Vaginal & 17.2 & 1.6 & - & 4.7 \\
\hline & Oxytocin & 13.8 & 1.5 & - & 9.2 \\
\hline \multirow{2}{*}{ Ralph et al } & Vaginal & 13 & 0 & - & - \\
\hline & Oxytocin & 18 & 5 & - & - \\
\hline \multirow{2}{*}{$\begin{array}{c}\text { Abramovici } \\
\text { et al }\end{array}$} & Oral & 8.2 & 8.16 & - & 5.2 \\
\hline & Oxytocin & 8.1 & 9.1 & - & 13.2 \\
\hline \multirow{2}{*}{ Adair et al } & Oral & 14 & 2.1 & - & 18.3 \\
\hline & Vaginal & 10 & 3 & - & 12.9 \\
\hline
\end{tabular}

Oxytocin group had less number of babies born with Apgar $<7$ at 5 mins as compared to vaginal misoprostol comparable with the results of Luis et al.

\begin{tabular}{|c|c|c|c|}
\hline \multicolumn{2}{|c|}{ Characteristic } & Apgar Score at $1 \mathrm{~min}$ & Apgar Score at 5 mins \\
\hline \multirow{4}{*}{ Present Study } & Oral & 6.5 & 8.4 \\
\hline & Vaginal & 6.2 & 8.2 \\
\hline & Oxytocin & 6.5 & 8.4 \\
\hline & Spont Labour & 6.4 & 8.7 \\
\hline \multirow{2}{*}{ Ernest Study } & Oral & 8.72 & 9.45 \\
\hline & Spont Labour & 7.68 & 8.93 \\
\hline
\end{tabular}

In present Study, the Apgar scores at 1 and 5 minutes were not significant between the groups. 
No neonatal deaths occurred in the present study.

Maternal complications were found to be lowest in oxytocin group. Even though 4 cases of tachysystole occurred with the use of oxytocin and 3 cases with vaginal misoprostol, the effect was reversible in minutes without any maternal and foetal morbidities and mortalities.

\section{CONCLUSION}

We can draw from this study that while induced labour may increase the chance of caesarean section, it does not adversely affect foetomaternal outcome. We therefore conclude that induced labour can be a safe procedure among nulliparous women, if labour is partographically monitored.

In the present study, it has been observed that oxytocin was a better inducing agent because it was associated with shorter induction to delivery time, route of delivery does not differ and less maternal and perinatal complications. Oxytocin administration could be halted at any time and then again restarted. In addition, with the half-life of oxytocin being in minutes, the dosage and frequency could be easily controlled. However, oxytocin administration was an invasive procedure, costlier and caused restricted ambulation of the patient.

\section{REFERENCES}

[1] ACOG Committee on Practice Bulletins - Obstetrics. ACOG practice bulletin No. 107: induction of labor. 2009;114(2 Pt 1)):386-97.

[2] Biswas A. Induction of labour: recent trends. Chapter2. In: Gupta DS. edr. Recent advances in obstetrics \& gynecology. New Delhi: Jaypee Brothers 1999:13-31.

[3] O’Brien WF, Knuppel RA, Cohen GR. Plasma prostaglandin metabolite levels after use of prostaglandin E2 gel for cervical ripening. Am J Obstet Gynecol 1986;155(5):1037-40.
[4] Biswas A, Arulkumaran SG. Induction of labour. Chapter-14. In: Arulkumaran SG. edr. The management of labour. Orient Longman 1996: p. 213.

[5] Kramer RL, Gilson GJ, Morrison DS, et al. A randomized trial of misoprostol and oxytocin for induction of labor: safety and efficacy. Obstet Gynecol 1997;89(3):387-91.

[6] Sanchez-Ramos L, Chen AH, Kaunith AM, et al. Labor induction with intravaginal misoprostol in term premature rupture of membranes: a randomized study. Obstet Gynecol 1997;89(6):909-12.

[7] Sanchez-Ramos L, Peterson DE, Delke I, et al. Labour induction with prostaglandin E1 misoprotosal compared with dinopostone vaginal insert: a randomised trial. Obstet Gynecol 1998;91(3):401-5.

[8] Adair CD, Weeks JW, Barrilleaux S, et al. Oral or vaginal misoprostol administration for induction of labor: a randomised, double-blind trial. Obstet Gynecol 1998;92(5):810-3.

[9] Wing DA, Paul RH. Induction of labor with misoprostol for premature rupture of membranes beyond thirtysix weeks gestation. Am J Obstet Gynecol 1998;179(1):94-9.

[10] Wing DA, Rahall A, Jones MM, et al. Misoprostol: an effective agent for cervical ripening and labor induction. Am J Obstet Gynaecol 1995;172(6):1811-6.

[11] Abramovici D, Goldwasser S, Mabie BC, et al. A randomised comparision of oral misoprostol versus foley catheter and oxytocin for induction of labour at term. AJOG 1999;181(5 Pt 1):1108-12.

[12] Orji EO, Olabode TO. Comparative study of labour progress and delivery outcome among induced versus spontaneous labour in nulliparous women using modified WHO partograph. NJOG 2008;3(1):24-8. 